\title{
Perceptions and Stereotypes Regarding the Participation of Women in Public Office: Advances or Static Conditions?
}

\author{
Delina Margarita NañezCórdova ${ }^{1}$, Flor Ivett Reyes Guillén ${ }^{2 *}$, Werclain Alejandro Gómez \\ Flores ${ }^{1}$, Socorro Fonseca Córdoba ${ }^{3}$, Raúl Vázquez Gutiérrez ${ }^{4}$, Miguel Ángel Cordero \\ Molina ${ }^{5}$, Mercedes Alejandro Pérez ${ }^{6}$ \\ ${ }^{I}$ PhD in Public Law from the University of the South. Professor-Researcher at the Faculty of Law C-III of the \\ UNACH. Centro Historico. C.P. 29220 San Cristóbal de las Casas, Chiapas Mexico \\ ${ }^{2}$ PhD in Sciences, Natural Resources and Sustainable Development from. Faculty of Social Sciences of the \\ Autonomous University of Chiapas, Mexico \\ ${ }^{3} \mathrm{PhD}$ in Education from the Institute of University Studies. Teaching researcher at the Faculty of Social \\ Sciences, Campus III, UNACH, Chiapas Mexico \\ ${ }^{4}$ Master's in psychology Professor-researcher of the Faculty of Law of the Autonomous University of Chiapas, \\ Mexico \\ ${ }^{5}$ Master's in constitutional law with training in Amparo by the Autonomous University of Chiapas, Mexico \\ ${ }^{6}$ PhD in Education Sciences from San Marcos University. Degreeinlaw and master's in criminal sciences. \\ Specialist in criminal,civil and procedural law. San Marcos University, Plantel San Cristóbal de las Casas, \\ Chiapas, Mexico \\ *Corresponding Author: Flor Ivett Reyes Guillén, PhD in Sciences, Natural Resources and Sustainable \\ Development from. Faculty of Social Sciences of the Autonomous University of Chiapas, Mexico

\begin{abstract}
This article presents the results of a study carried out with the objective of knowing the perceptions of university students in relation to the participation of women in public office. The finding related to the existence of a representative percentage of young people who do not agree with the participation of the woman in public office or the empowerment of the women is relevant. It is also important to recognize the lack of information and educational programs related to gender equity in the educational area to which they belong in their vocational training process.The conditions are not static; but it is necessary to carry out studies like the present one, which must be replicated and directed towards other scenarios.
\end{abstract}

Keywords: Perceptions, gender, university youth

\section{INTRODUCTION}

In this document we discuss the results of a study conducted to learn about the perceptions of young university students in relation to the participation of women in public office, leading to discussion on the clarity of progress or conditions the public performance of women's lives.

To this end, briefly but emphatically, it is necessary to consider what the United Nations Organization has been discussing, analyzing and proposing in recent decades. The ONU (2015) highlights the importance of achieving gender equality not only in terms of law support, but in daily practice for attention to the fundamental commitment of human rights.

It is undeniable that ensuring this inclusion and equal rights and opportunities leads us to think of a sustainable and democratic society. The ONU (2015), also talks about the recognition of the work done in the legal and educational field that allows the protection of women and girls, and the search for equal opportunities. However, there is still a long way to go to achieve real equality and a greater advance is looming for the year 2030 encouraging member countries to work for a "Planet 50-50".

However, the political participation of women in Mexico has been the result of a joint work of several decades, struggles and social movements carried out by the women themselves, nevertheless, we are still immersed in a world where the political spaces and Institutions are mostly male. 
In Mexico, within the current legislation, it is clear the legal equality of women and men, which generates rights and clear obligations and frames the social coexistence of our country. Also, the Magna Carta of the Mexican state contemplates the political and legal status of women, specifically it is established in their lines that women and men have equal rights and equal obligations, to others and to the state.

Although progress has been made in legal matters to safeguard the rights of women and girls, there are few studies to learn about the perceptions that people have about the inclusion of women in public life and their image in charge Political and institutional that have conferred on them to represent this advance towards the attainment of planet 50-50.

It is now recognized that women play an important role in building a sustainable, fair, egalitarian, respectful society (Salinas, 2005). However, patriarchy and gender inequities still exist limit the potential of women's empowerment (CEPAL, 2001). But the progress made in recent decades has resulted in ways of transforming women's living conditions and ensuring that they continue to move forward to achieve equity.

But speaking specifically about women's empowerment, it covers different factors related to the processes of social participation (IEEZ, 2014), culture, generational gaps.

In this case, the present document is the result of this research process that allows us to know the perceptions and the knowledge that young university students have regarding the inclusion of women in public life. The context in which it is carried out is considering young university students enrolled in law degree, who live and develop in San Cristóbal de Las Casas, Middle City, multicultural, important area of cultural interest; But with a high degree of lag as is the state to which it belongs, Chiapas in Mexico.

\section{RESEARCH METHOD}

The study was carried out in the Faculty of Law of the Autonomous University of Chiapas, in the period of August-December of the 2018, under the design of a random sampling and under informed consent of the participants, considering that the sample is Distribute in equal proportion of men and women.

Considering the total population of young people enrolled, the size of the sample was determined using the formula:

$$
n=\frac{N \cdot Z^{2} \cdot p \cdot(1-p)}{(N-1) \cdot e^{2}+Z^{2} \cdot p \cdot(1-p)}
$$

Which gives us the $95 \%$ confidence and 5\% accuracy, obtaining a sample of $\mathrm{n}=120$, where:

$n=$ Sample size.

$p=$ Proportion to estimate.

$Z=$ Number of a normal distribution associated with a desired confidence level.

$e=$ Maximum acceptable relative error

An interview instrument was applied for analysis of perceptions with twelve items and as general data age and gender.

\section{RESULTS AND ANALYSIS OF INVESTIGATIONS}

The results of the study showed evidence from knowledge of international laws and treaties related to women's rights, perceptions of women's empowerment, women in public office, rights Work of women, organizational environment of their institution with respect to the coexistence of both genders and the inclusion of women in administrative positions of means and high command.

\subsection{Knowledge of Laws and Treaties Related to Women's Rights}

$30 \%$ of respondents do not know them and $70 \%$ claim to know them. They are then listed in order of greater to lesser knowledge of their existence the following: 
- General law for equality between men and women.

- General Law of access to women to a life free of violence.

- Convention on the Elimination of All Forms of Discrimination against Women.

- Resolution on the participation of women in politics.

- Optional Protocol to the Convention on the Elimination of All Forms of Discrimination against Women.

- Inter-American Program on the Promotion of Women's human rights and gender equity and equality.

- Statute of the security mechanism for the implementation of the Inter-American Convention to Prevent, Punish and eradicate Violence against women.

About the regional Program of Action for Women in Latin America and the Caribbean, 59\% of those interviewed do not know or know very little about this document and strategy.

\subsection{Knowledge of Associations, Non-Governmental Organizations or Government Agencies that Address the Protection of Women and the Recognition of their Rights}

On this point, the interviewees know little, only $47 \%$ managed to mention in order of higher to lower frequency the following:

1. Secretariat for the development and empowerment of women (government instance)

2. Fortress of the Mayan Woman, A.C. (Civil Association)

3. Inmujeres (government instance)

\subsection{Within the Information Obtained Specifically on the Perception Concerning the Topic Addressed we Must}

- $21 \%$ of respondents disagree with women's empowerment. $75 \%$ if they agree and the remaining $4 \%$ were undecided with their position on it.

- $55 \%$ are fully in agreement with the participation of women in civil service positions. $44 \%$ do not fully agree and the remaining percentage disagree.

- Specifically, the perception they have about the importance that has given the right to the participation of women in positions of the public service, to $42 \%$ It seems excellent, for the $48 \%$ is good the action, for the remaining percentage (10\%) It is considered as little or no suitable.

- $80 \%$ of the young people who participated in the study consider that women's labor rights have been violated reflecting in events such as: a) discrimination in their workplaces and in other areas; b) Psychological and verbal violence and c) exclusion.

However, in relation to their immediate surroundings, the university students make evident the following data:

- $90 \%$ do not know of any project that their university has directed towards the participation of women in different professional fields.

- $47 \%$ Consider the possibility of a woman serving as rector or maximum authority in the university as excellent. At $38 \%$ only the idea seems good. The remaining percentage is little or no according to the idea (15\%).

- In considering the perception regarding the work that the university does to include the topic of gender in the academic activities, $45 \%$ mentions that it goes from regular too bad; $38 \%$ considers it good; only $17 \%$ consider it excellent.

As an integrative element, the perception that young university students have regarding the equal participation of women in the public service is excellent and coherent with the international perspective in $75 \%$; Of the remaining percentage (25\%), still high, consider that it should not exist $(5 \%)$ Or they prefer not to answer. 
The results of this study allow us to see clearly that the work that we must do at the educational level is still arduous, both in its formal modality at all educational levels; As in its non-formal modality within family structures and empirical knowledge transmitted through the generations. We cannot have a society that seeks gender equity and equal opportunities among all genders if our culture does not transcend the barriers that oppose the visualization of women in all spaces, as well as gender equity.

Faced with this issue we do not find only the structural and economic or political constraints; But cultural stereotypes in society also limit and hinder the implementation of international agreements (Fernandez, 2012).

If we understand perceptions as a cognitive process of the consciousness of the physical and social world, then experience-based representations of reality are built (Vargas, 1994). In this study, the results related to perceptions show us that in high percentage the participation of women in public offices is not yet seen or accepted and the empowerment of this genre is not facilitated. Paradoxically, if the violation of women's labor rights in various forms such as discriminatory manifestations, psychological and/or verbal violence and acts of exclusion are recognized in a high percentage.

However, the above can be understood if we consider that in their immediate environment, they are not perceiving actions related to the pursuit of gender equity. Among the results is a high percentage of young university students who do not know a program on gender issues that promotes their university, or concrete actions in this regard. This in turn can be explained by mentioning the mental feelings that evoke or recall mental configurations of personal experiences, creating what for Moscovici (1979), Ibañez (1988) and Araya (2002), would be the formation of a screen selective outside.

Within this reality we form stereotypes or attitudes and postures in relation to the outside and express judgments and thus derive actions which, of course, will be stereotyped and even stigmatized depending on the choice of the individual Triggering in discriminatory actions (Goffman, 2003), under their own perceptions and perceptions shared with the collective to which they belong.

In matters of lack of recognition and respect for women's rights, an event that has been historically and continuously unsurpassed in its entirety, prejudices, derogatory assessments, stereotyped opinions, generate or lead to attitudes Negative, hostile behaviors and exclusion (Allport, 1968; Huici, 1996; Casas, 1999; Lippman, 2003), which is why it can be understood; But not to be naturalized, the existence of a high percentage of young university students who still oppose the visibility of the female gender in the public sphere.

\section{CONCLusions}

As a conclusion, we will make the following statements, if the university students of the law degree who participated in this study are a representation of individual cognitive processes resulting from perceptions Both the immediate environment and the society to which it belongs:

1. The young university students interviewed know, for the most part, the laws and treaties related to the rights of women.

2. Less than half of these young people are familiar with associations, non-governmental organizations and government agencies that address the protection of women and the recognition of their rights.

3. A percentage of those interviewed, small but not to be invisible, do not agree with the empowerment of women, nor does it seem appropriate that from the right, women's participation in public service positions is encouraged.

4. It is high the percentage of young people who, if they recognize the existence of violation of the labor rights of the women, being the most frequent discrimination, psychological and verbal violence, exclusion.

The conditions are definitely not static; but it is necessary to carry out studies like the present one, which must be replicated and directed towards other scenarios, to know how the problems of gender are perceived, the invisibilization of the women and the possible routes of intervention and sensitization to a Serious problem and on which international work, wanting not only to find equity, equal opportunities, but also security of a gender that has historically been highly vulnerable. 


\section{REFERENCES}

[1] ONU. (2015). La ONU en Acción para la Igualdad de Género en México. Organización de las Naciones Unidas.

[2] Salinas P. (2005). Ciudadanía y género: mujeres y liderazgo en las provincias de Antofagasta, el Loa y Tocopilla [en línea]. Disponible en internet: URL:http//www2.udec.cl/serví/numero5/ion04.htm.

[3] CEPAL. (2001). Políticas para el empoderamiento de las mujeres como estrategia de la lucha contra la pobreza [en línea]. Disponible de Internet: URL:http://www.cepal.org/politicas/mujer

[4] IEEZ. Instituto Electoral del Estado de Zacatecas (2014). Participación de las Mujeres en la Vida Política e Institucional del Estado de Zacatecas.

[5] Fernández,PAM. (2012). "Mujeres al poder". Voz y voto 229, marzo, México.

[6] Vargas,MLM. (1994). "Sobre el concepto de percepción”. Alteridades 8.47-53

[7] Moscovici, S. (1979). El psicoanálisis, su imagen y su público. Buenos Aires: Huemul.

[8] Ibáñez,GT. (1988). "Representaciones sociales: teoría y método". Ideologías de la vida cotidiana, coordinado por Tomás Ibáñez Gracia. Barcelona: Sendai.

[9] Araya,US. (2002). Las representaciones sociales: ejes teóricos para su discusión. San José: Facultad Latinoamericana de Ciencias Sociales.

[10] Goffman, E. (2003). Estigma. La identidad deteriorada. Buenos Aires: Amorrortu.

[11] Allport, GW. (1968). La naturaleza del prejuicio. Buenos Aires: Eudeba.

[12] Huici, C. (1996). "Estereotipos". En Psicología social, coordinado por Francisco J. Morales y Carmen Huici. Madrid: McGraw-Hill.

[13] Casas,CM. (1999). "Cambio de actitudes en contextos interculturales en Barcelona: actividades lúdicas y modificación de prejuicios". Scripta Nova. Revista Electrónica de Geografía y Ciencias Sociales.

[14] Lippmann, W. (2003). La opinión pública. Madrid: Lagre.

\section{AUTHORS' BIOGRAPHY}

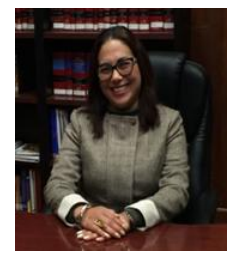

Delina Margarita NañezCórdova, Doctorate in Public law by the University of the South, master in Psych pedagogy by the Autonomous University of Chiapas, degree in pedagogy by the Autonomous University of Chiapas, and the degree in law by the San Marcos University. Professor-researcher ascribed to the Faculty of Law C-III of the UNACH, teaching the subjects of contemporary juridical systems, history of the law and of the human rights, and commercial law.

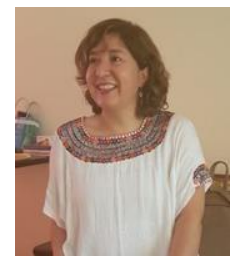

Flor Ivett Reyes Guillén, $\mathrm{PhD}$ and master's in Science from the ECOSUR. Member of the academic corps "Society, culture and education", UNACH. Desirable profile PRODEP. President of the Research Network on public Health and Developmental Problems, REINVESAD. LGAC Society, sustainability and health. Political culture and education. Last three publications: Article: From reasoning to practice: perceptions of sexual health self-care. Published: 26/04/2018 Vol. XIII; No. 7; 522 Portalesmedicos.com ISSN 1886-8924 Book: Coord. Public Health, culture and education. ISBN 78607-8573-29-5 Book Cap: Importance of measuring quality of service in a higher education institution. In Reyes-Guillén FI and AB Palacios Gámaz Coord. 2017. When we talk about a diverse Chiapas. Contributions of the Reinvesad. ISBN 978-607-8459-605

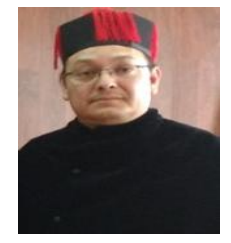

Werclain Alejandro Gómez Flores, Ph.D. in public law from the University of the South, master's in organizational psychology from the University of the South, B.A. in pedagogy from the Autonomous University of Chiapas, and the degree in law by the San Marcos University. Professor of ascribed to the Faculty of Law C-III of the $\mathrm{UNACH}$, imparting the matter of deontology and juridical ethics.

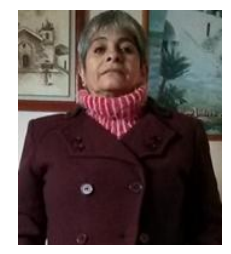

Socorro Fonseca Córdoba, $\mathrm{PhD}$ in Education from the Institute of University Studies, Master's in economics from the National Autonomous University of Mexico. Member of the academic corps "Society, culture and education". LGAC Society, sustainability and health. Political culture and education. Member of the Research Network on Public Health and Developmental Problems, Reinvesad. Publications:Book"School trajectory of the students of the degree in economy generation 2004-2008 in the Faculty of Social Sciences, Campus III, UNACH”. Book Cap. IX 
Ancestry and modernity: the dispute over water in San Cristóbal de Las Casas, Chiapas(COMECSO, 2018) and chapter of $X$ dating violence/couple: Common trunk Faculty of Social Sciences, UNACH (COMECSO, 2018).

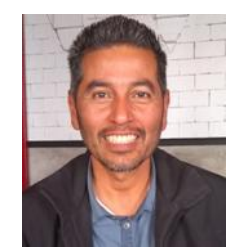

Raúl Vázquez Gutiérrez, Master in community psychology at the University of Chile from 2004 to 2006. Speaker in Congresses in Havana, Cuba and in Santiago de Chile, as well as in different national forums. LGAC "Human rights: sexual and reproductive rights in young people". Books: "HIV/AIDS and sexuality, different looks" edited by the Autonomous University of Chiapas 2012 and "Housewives a anachronistic concept for de XXI century" 2014. Book cap. in "an approach to social science research" 2015. Publication of the master's thesis at the University of Chile in the document "Master's thesis in Community Psychology Compendium Vol. 1".

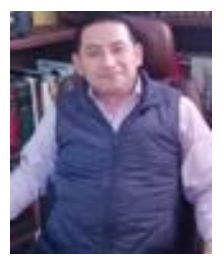

Miguel Ángel Cordero Molina, Lecturer in Congresses of the Houses of juridical culture of the Supreme Court of Justice of the nation, as well as in different local and national forums. His line of research is "human rights: gender equality in the delivery of justice in food matters", according to this public article "the payment of the pension to alimentary in the Altos de Chiapas, visible in the journal University and Knowledge $\mathrm{He}$ has also participated in writing chapters in books, such as "Constitutional Law of religion" in 2014. In addition, in 2015, I conducted a research stay at the InterAmerican Institute of Human Rights (IIDH), in San José, Costa Rica, within the framework of the Conference on Human Rights and the Inter-American human rights system. He is also president of the Local Board of Directors of the Mexican Red Cross delegation San Cristóbal for the period 20182020.

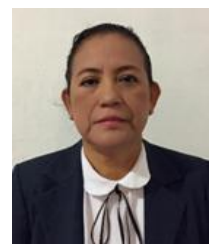

Mercedes Alejandro Pérez, $\mathrm{PhD}$ in Education Sciences. Professor in the area of crime theories, criminal process, criminology, legal research and educational policies.

Citation: Delina Margarita NañezCórdova, etal.. "Perceptions and Stereotypes Regarding the Participation of Women in Public Office: Advances or Static Conditions?". International Journal of Humanities Social Sciences and Education (IJHSSE), vol 6, no. 3, 2019, pp. 27-32. doi: http://dx.doi.org/10.20431/23490381.0603004.

Copyright: (C) 2019 Authors. This is an open-access article distributed under the terms of the Creative Commons Attribution License, which permits unrestricted use, distribution, and reproduction in any medium, provided the original author and source are credited. 